Egypt. Acad. J. Biolog. Sci., 12(2):1-21 (2020)

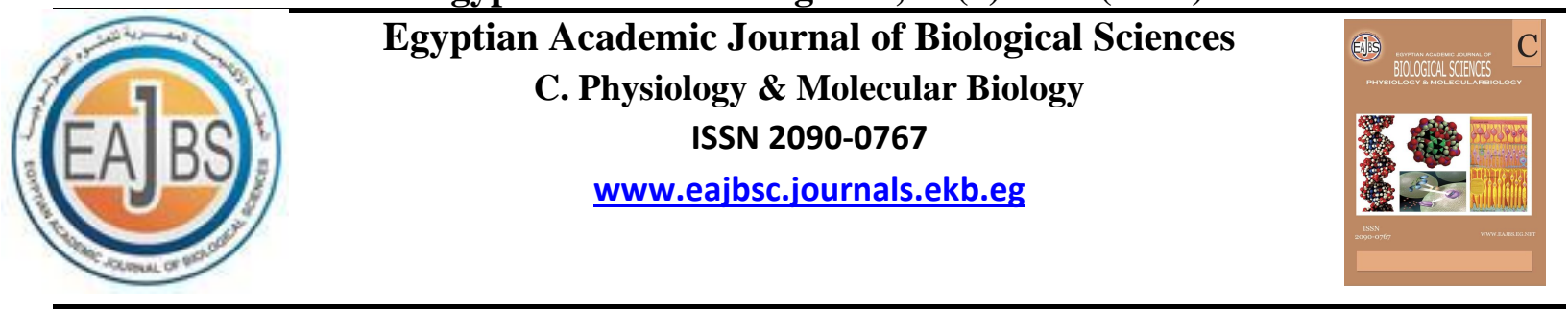

Molecular Characterization of Betaine Aldehyde Dehydrogenase $(B A D H)$ Gene and Proline Estimation in Hordeum vulgare L. in Response to Abiotic Stress

\author{
H. El-Atroush ${ }^{1 *}$, Essam A. H. Mostafa ${ }^{2}$, and Samira A. Osman ${ }^{2}$
}

1- Botany Department, Faculty of Science, Ain Shams University, Abassia, Cairo, Egypt.

2- Department of Genetics and Cytology, National Research Center, Dokki, Giza, Egypt

E.Mail: hala elatroush@hotmail.com

ARTICLE INFO

Article History

Received: $14 / 4$ /2020

Accepted: 2/ 7/2020

Keywords:

Hordeum vulgare

L., abiotic stress,

$B A D H$ gene

sequencing,

proline., molecular

characterization .

\begin{abstract}
Barley possesses the highest level of salt tolerance among cereals, thus it is used as an important species to investigate mechanisms involved in salt tolerance. The present investigation was conducted to study the effect of salt stress by different $\mathrm{NaCl}$ concentrations $(0,9000,12000$, and $15000 \mathrm{ppm})$ on proline production and it was found that there is a positive correlation between proline production and salinity. Also study the effect of salinity on $B A D H-1$ gene expression by Real-Time PCR, where this gene was performed and it was aligned in GenBank. The sequencing was translated into amino acid sequences and these amino acid sequences were aligned in GenBank. Finally, the secondary structure of $B A D H-1$ enzyme was determined from the most tolerant barley (Giza 2000 and Wadi Sedr) and sensitive barley Giza 129 cultivars, then sequencing translated into amino acid sequences and these sequences were aligned in GenBank. Finally, the secondary structure of $B A D H-1$ enzyme was determined. These isolated genes were submitted in GenBank under accession numbers KX433169, KX342849, KX342850, KX342851, KX433170, and KX433171.
\end{abstract}

\title{
INTRODUCTION
}

Salinity is one of the serious problems affecting one-third of the irrigation land nearly 950 million ha land in the world, also, it has an important effect on plant growth and productivity of modern cultivars (Maas and Hoffman, 1977; Babu et al., 2007 and Munns, 2002). In Egypt, there are about two million feddans of the irrigated land adversely affected by the accumulation of salts. This environmental stress is a complex trait controlled by a large number of genes which makes them elusive to selection for tolerance by conventional breeding programs (Abo-Elenin et al., 1981).

For the overcoming of salt stress problems, plants have evolved complex mechanisms that contribute to the adaptation to osmotic and ionic stress caused by high salinity. During the onset and development of salt stress within a plant, all the major processes such as compatible osmolytes, protein synthesis, and lipid metabolism are affected. The resistance or sensitivity to salt stress depends on the species, the genotype, and the development age of the plants.

Compatible osmolytes are potent osmoprotectants that play an important role in facing the osmotic stress. Proline, glycine betaine, polyamines, and carbohydrates have been described as being effective against salt stress by (Hare and Cress, 1997). 
These compatible osmolytes show rapid and quantitatively important changes in their concentrations following variation in salinity (Fathi-Ettai and Prat, 1990).

Proline accumulation induced by drought and salt stress in plants is also involved in stress resistance mechanisms. Their possible roles have been attributed to stabilizing the structure of macro-molecules and organelles through stabilizing proteins and membranes against the denaturation effect of high concentrations of salts and other harmful solutes (Munns, 2002).

Plant abiotic stress response is mediated by increasing $B A D H$ gene activity (Nakamura et al., 2001). BADH transcript levels were more abundant under salt stress than control in barley (Fujiwara et al., 2008). Barley has a diploid number of chromosomes $2 \mathrm{n}=14$ also, it has two $B A D H$ paralogs, $B A D H 1$ gene located on chromosome 4 and $B A D H 2$ gene on chromosome 8 (Singh et al., 2010). In barley, $B A D H 2$ mainly expressed in leaf cytosol, while $B A D H 1$ expressed in leaf peroxisomes (Fujiwara et al., 2008).

Betaine aldehyde dehydrogenase $(B A D H)$ is an important enzyme, which has dual roles in cereals influencing rice fragrance and abiotic stress tolerance. First role: A mutation in some $B A D H 2$ alleles introduces a termination codon which causes truncation of the protein and ultimately elevates the level of 2 acetyl-1-pyroline (2AP), leading to fragrance in rice (basmati and jasmine rice) and soybean as shown in figure (1) (Shrestha, 2011).

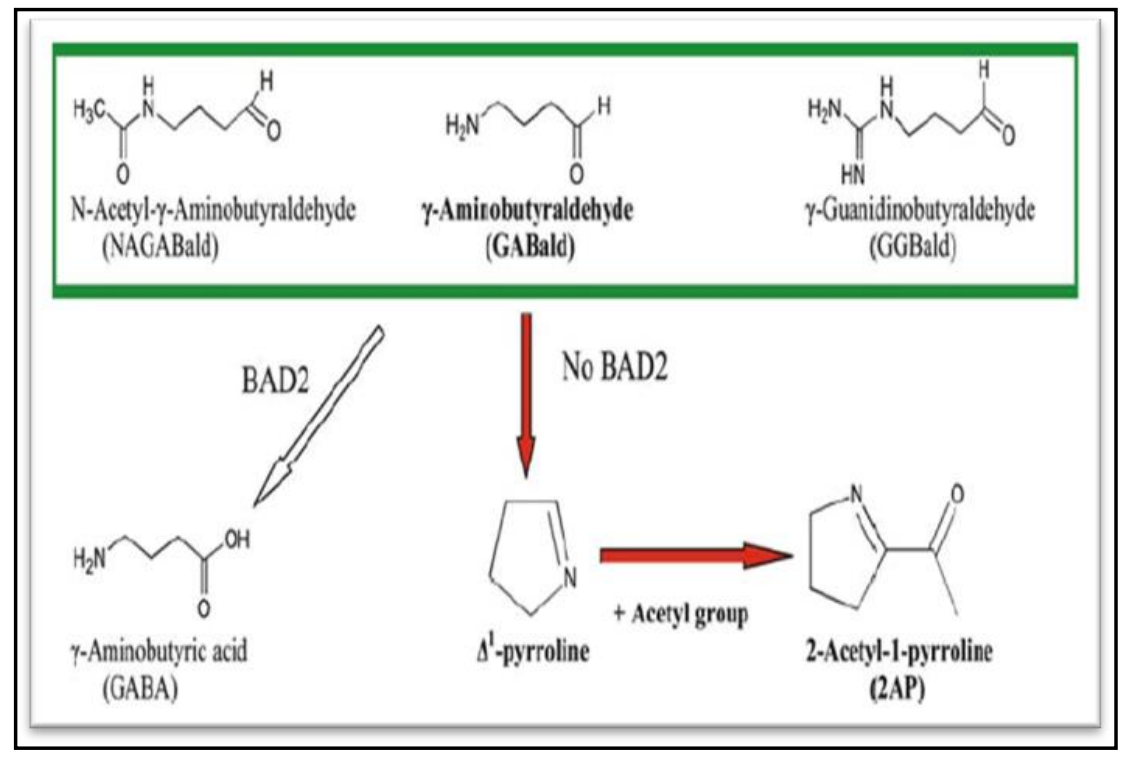

Fig. 1: A mutation in some $B A D H 2$ alleles

Second role: Betaine aldehyde dehydrogenase $(B A D H)$ enzyme also plays an important role in defined mechanism to abiotic stress as salinity, cold temperature, and draught (Le Rudulier et al., 1984 and Kishitani et al., 1994), it catalyzes the conversion of betaine aldehyde (BA) to glycine betaine $(\mathrm{GB})$, this reaction is dependent on oxidizing the co-factor NAD+ or NADP+ as shown in figure (2) (Weigel et al., 1986; Nakamura et al., 1997 and Mori et al., 2002). Glycine betaine (GB) is accumulated in several higher plant families such as Chenopodiaceace, Podiaceace, and Adteraceae (Ishitani et al., 1993). It is predominantly accumulated in the leaves and stems from a diverse range of dicotyledons and some monocotyledons (Ishitani et al., 1993). Glycine betaine (GB) protects the cell under stresses by maintaining the osmotic balance between the intracellular and extracellular compartments of cells in 
addition to stabilizing enzymes and biomolecules (Robinson and Jones, 1986).

Glycine betaine, which is an amazing amino acid, functions as an osmotic protectant in plant responses to various environmental stresses. This important compound can protect the photosystem II complex, the biomembrane system, and numerous useful proteins from destructive stresses through providing osmotic adjustment. The expression of the BADH and CMO genes is greatly induced by different abiotic stresses leading to the high agglomeration of glycine betaine and consequently enhancing the tolerance to a wide range of stresses in many crops $(\mathrm{Yu}$, et al., 2017).

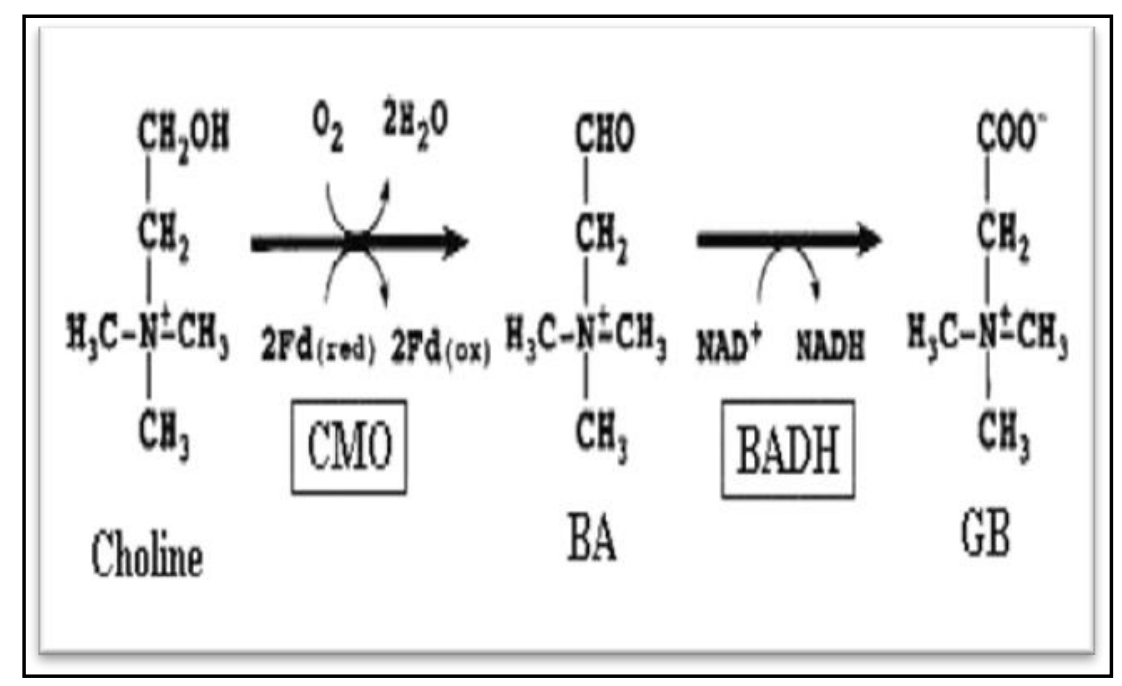

Fig 2: the conversion of betaine aldehyde (BA) to glycine betaine (GB)

Betaine aldehyde dehydrogenase $(B A D H)$ and choline monooxygenase (CMO) work together, CMO converts choline, a derivative of proline, to betaine aldehyde and $\mathrm{BADH}$ converts betaine aldehyde to glycine betaine. These enzymes are compartmentalized within the chloroplast in plants (Weigel et al., 1986) with both reactions taking place depending on the presence and length of exposure to light (Hanson et al., 1985 and Weigel et al., 1988).

The aim of the present study was to determine the tolerant barley cultivar and sensitive one against the salt stress and make recommendations for using the best one. Also, study the effect of salt stress by different $\mathrm{NaCl}$ concentrations on proline production from each cultivar and study the effect of salinity on Betaine aldehyde dehydrogenase 1 ( $B A D H-1)$ gene expression by using Real-Time PCR, where this gene was performed and it was aligned in GenBank. Molecular characterization of
$(B A D H-1)$ gene was carried out from the most tolerant and sensitive cultivar, where, the sequencing of the gene was translated into amino acid sequences, which were aligned in GenBank, finally, the secondary structure of BADH-1 enzyme was detected.

MATERAILS AND METHODS Extraction and Estimation of Proline:

Free proline was determined according to Bates et al. (1973). Acid ninhydrin reagent was prepared by warming $1.25 \mathrm{~g}$ ninhydrin in $30 \mathrm{ml}$ glacial acetic acid and 20 $\mathrm{ml} 6 \mathrm{M}$ phosphoric acid with agitation until dissolved; kept cool and stored at $4{ }^{\circ} \mathrm{C}$. The reagent remains stable for 24 hours.

Approximately one gram of macerated fresh leaves was homogenized in $10 \mathrm{ml}$ of 3 $\%$ aqueous sulfosalicylic acid and then filtered through filter paper Whatman No.2. Two $\mathrm{ml}$ of the filtrate were mixed with $2 \mathrm{ml}$ glacial acetic acid and $2 \mathrm{ml}$ of acid ninhydrin reagent in a test tube and heated for one hour at $100{ }^{\circ} \mathrm{C}$. The reaction mixture was extracted with $4 \mathrm{ml}$ toluene, mixed 
vigorously in the test tube for 15-20 seconds. The chromophore containing toluene was aspired from the aqueous phase and warmed to room temperature. The absorbance was read at $520 \mathrm{~nm}$ using toluene as a blank using spectrophotometer (Spectronic 601, Milton Roy Company). Proline concentration was determined using a standard curve and expressed as $\mu \mathrm{g}$ proline $\mathrm{g}^{-1} \mathrm{FW}$.

Isolation and Sequencing of Betaine Aldehyde Dehydrogenase1 (BADH-1) gene DNA Isolation:

DNA was isolated from three Hordeum vulgare L. varieties by using Gene Jet Plant Genomic DNA Purification Mini Kit (thermo Scientific K0791).

\section{RNA Extraction:}

SV Total RNA Isolation System Spin Protocol (Promega, U.S.A.) was used for extraction of RNA.

cDNA Synthesis:

RevertAid First Strand cDNA Synthesis Kit (thermo, Germany) was used to synthesis cDNA from total RNA. Firststrand cDNA synthesis for different isolated
RNA was performed in $0.2 \mathrm{ml}$ PCR Eppendorf containing $(20 \mu \mathrm{l})$ consisted of template RNA $(5 \mu \mathrm{l})$, Primer oligo (dt) 18 primer $(1 \mu 1), 5 X$ reaction buffer $(4 \mu 1)$, RiboLock RNase inhibitor $(1 \mu \mathrm{l}), 10 \mathrm{mM}$ dNTP Mix $(2 \mu \mathrm{l})$ and RevertAid M-MuLV reverse transcriptase $(1 \mu \mathrm{l})$ then completed to $20 \mu \mathrm{l}$ by nuclease-free water. For oligo (dT) 18 or gene-specific primed cDNA synthesis, incubate for $60 \mathrm{~min}$ at $42^{\circ} \mathrm{C}$ then terminate the reaction by heating at $70^{\circ} \mathrm{C}$ for $5 \mathrm{~min}$ by Thermocycler (Bio-Rad).

\section{Betaine Aldehyde Dehydrogenase1 $(B A D H-1)$ gene Isolation From Genomic DNA and CDNA:}

Genomic DNA and cDNA from Giza 129, Giza 2000 cultivars, and Wadi Sedr landrace in seedling stage (2 or 3-week old plant) were subjected to a polymerase chain reaction (PCR) for 30 cycles with $\mathrm{BADH} 1$ Primer (Shrestha, 2011). This primer designed from $B A D H 1$ sequences was obtained from the NCBI databases with the following accession numbers Hordeum vulgare $\mathrm{BADH} 1$ (AB161712) as shown in table (1).

Table (1): Primers used for the amplification of $B A D H-1$.

\begin{tabular}{|l|l|l|l|}
\hline $\begin{array}{l}\text { Homologs, } \\
\text { Primer pairs }\end{array}$ & Forward primer (5'-3') & Reverse primer (5'-3') & $\begin{array}{l}\text { Expecte size } \\
\text { of amplicon }\end{array}$ \\
\hline $\begin{array}{l}\text { BADH1 } \\
\text { (from DNA) }\end{array}$ & CAGCAAGAAGTGAAGGTGCTAC & GTACCTGGTGACTTGTTTCACG & $\sim 750$ bp \\
\hline $\begin{array}{l}\text { BADH1 } \\
\text { (from cDNA) }\end{array}$ & CAGCAAGAAGTGAAGGTGCTAC & GTACCTGGTGACTTGTTTCACG & $\sim \mathbf{4 1 0}$ bp \\
\hline B-Actin & GTTCCAATCTATGAGGGATACACGC & GAACCTCCACTGAGAACAACATTACC & $\sim \mathbf{4 2 2}$ bp \\
\hline
\end{tabular}

PCR amplification for isolation $B A D H$ gene from genomic DNA and cDNA was performed in $0.2 \mathrm{ml}$ PCR Eppendorf containing $(50 \mu \mathrm{l})$, which consisted of Dream Taq DNA Polymerase, Promega (1 $\mu 1)$, 10x Dream Taq Green Buffer $(10 \mu 1)$, $\mathrm{MgCl}(5 \mu \mathrm{l})$ dNTP were mixed $10 \mathrm{mM}$ each $(4 \mu \mathrm{l})$, primer forward (f) and reverse (r), Metabion, German $(3 \mu \mathrm{l})$ and template DNA $(4 \mu \mathrm{l})$ or cDNA $(2 \mu \mathrm{l})$. Then, all these components were completed to $50 \mu 1$ by water, nuclease-free. Thermocycler (BioRad) was programmed for 30 cycles in case of isolation from genomic DNA as follows: $95^{\circ} \mathrm{C}$ for $3 \mathrm{~min}$ (one cycle) then, $95^{\circ} \mathrm{C}$ for 30 sec, $58^{\circ} \mathrm{C}$ for $1 \mathrm{~min}$ and $72^{\circ} \mathrm{C}$ for $1.5 \mathrm{~min}$. While in case of isolation from cDNA as the follows: $94^{\circ} \mathrm{C}$ for $2 \mathrm{~min}$ (one cycle) then $94^{\circ} \mathrm{C}$ for $15 \mathrm{sec}, 57^{\circ} \mathrm{C}$ for $30 \mathrm{sec}$ and $72^{\circ} \mathrm{C}$ for 1.5 min (35 cycles).

Gel Preparation, Isolation And Sequencing of $B A D H-1$ gene:

Two grams of agarose were placed in 1/2x TAE buffer $(100 \mathrm{ml})$ and were boiled in water bath, then ethidium bromide was added to the melted gel after the temperature became $55^{\circ} \mathrm{C}$. The melted gel was poured in the tray of midi-gel apparatus and the comb was inserted immediately. Then the comb was removed when the gel became hardened. 
The electrophoresis buffer (1X TAE) was added and covered the gel. $10 \mu \mathrm{l}$ of DNA amplified product was loaded in each well and run at $100 \mathrm{~V}$ for about 2 hours. The gel was photographed and was analyzed by GelDocumentation 2000 system, USA. The expected size of $B A D H-1$ gene was appeared in the gel in genomic DNA a proximally at 750 and in cDNA at 410 under gel documentation. After that the purification of isolated gene was made from gel fragment by Clean Up Purification Kit (promega, USA) then the product was sequenced by sequencing apparatus in Macro-gene lab in Korea.

$B A D H-1$ gene was isolated and was sequenced. The forward and reverse was sequenced and was aligned by Bio-Edit program (Hall, 1999) to obtain the exact size of the sequencing of $B A D H-1$ gene which was isolated from gel fragment in genomic DNA and cDNA in Giza 129, Giza 2000 and Wadi Sedr.

$B A D H-1$ from genomic DNA in three varieties were aligned to each other on the basis of the phylogenetic relationship between three studied varieties was carried out with ClustalW by Mega 6.06 program (Tamura et al., 2013); also, the same step was repeated between $B A D H-1$ from cDNA sequence. The alignment was obtained by the Mega 6.06 program between $B A D H-1$ sequence in genomic DNA and in CDNA of the same variety to determine the exon region in the genomic BADH gene. Also, this gene sequence was identified in GenBank by alignment in nucleotide NCBI BLAST.

The sequence which was obtained from cDNA could be translated into amino acid sequences by the Mega 6.06 program then these amino acid sequences were identified by protein alignment NCBI BLAST.

Gene Expression of $B A D H-1$ gene Under Salt Stress by Real Time-PCR:

RNA was extracted from young leaves of Giza 129, Giza 2000 and Wadi Sedr by using RNA extraction Kits (Promega, USA) after 72 hours of treatments from control and $15000 \mathrm{PPm}$ treatment of $\mathrm{NaCl}$; then RNA was reverse transcribed with oligo d (T) primer using the Revert Aid Strand cDNA Synthesis $\mathrm{Kit}^{\mathrm{TM}}$ purchased from Thermo. The BADHI Primer was used as a positive control for a salt-induced gene while B-Actin was used as a house-keeping control. Realtime PCR, the $B A D H-1$ gene expression could be determined by the following equestions.

$$
\begin{aligned}
& \Delta \mathrm{CT}_{\text {untreatment }}=\mathrm{CT}_{\mathrm{BADH}-1 \text { gene }}-\mathrm{CT}_{\text {house-keeping gene }} \\
& \Delta \mathrm{CT}_{\text {treatment }}=\mathrm{CT}_{\mathrm{BADH}-1} \text { gene }-\mathrm{CT}_{\text {house-keeping gene }} \\
& \Delta \Delta \mathrm{CT}=\Delta \mathrm{C} \mathrm{T}_{\text {treatment }}-\Delta \mathrm{CT} \text { untreatment } \\
& \text { Gene expression }(\mathrm{RQ})=2^{-\Delta \Delta \mathrm{CT}}
\end{aligned}
$$

\section{RESULTS AND DISCUSSION}

\section{Effect of Salinity on Proline Content in Hordeum vulgare L. Varieties:}

The analysis of proline content in fresh leaves of ten Egyptian Hordeum vulgare L. showed highly significant differences. Also, the salinity treatments of different $\mathrm{NaCl}$ concentrations (control, 9000, 12000, and $15000 \mathrm{ppm}$ ) showed highly significant differences between the treated varieties and untreated varieties indicating a significant effect of salinity on the studied traits (table 2). Table (3) and figure (3) represent the mean performance of proline content in fresh leaves for ten Egyptian Hordeum vulgare L. varieties under different concentrations of sodium chloride (control, 9000, 12000 and $15000 \mathrm{ppm}$ ).

The optimum proline content $\left(\mu \mathrm{g} \mathrm{g}^{-1} \mathrm{FW}\right.$ ) was found in Giza 2000 were 11.29 and 24.11 in 12000 and 15000 ppm respectively, while the minimum proline content $\left(\mu \mathrm{g} \mathrm{g}^{-1} \mathrm{FW}\right)$ was reported in Giza 129 were 0.61 and 0.38 in 12000 and 15000 ppm respectively. In Giza 128, Giza 129 and Giza 130, it was found that the proline content increase as sodium chloride concentrations increase in control, $9000 \mathrm{ppm}$ then begin to decrease as sodium chloride increase in 12000 and $15000 \mathrm{ppm}$. 
Table 2: Mean square (MS) of proline content on fresh leaves on ten Hordeum vulgare L. varieties under salt stress of $\mathrm{NaCl}$.

\begin{tabular}{|c|c|c|}
\hline Source & Df & MS \\
\hline Repeat & 2 & $0.02^{\text {ns }}$ \\
\hline Treatment & 3 & $405.75^{* \star *}$ \\
\hline Varieties & 9 & $102.86^{* * *}$ \\
\hline Treatment $x$ varieties & 27 & $41^{* \star *}$ \\
\hline Error & 78 & 0.01 \\
\hline Total & 119 & 3250.9 \\
\hline
\end{tabular}

*: significant $\quad * *$ : moderately significant $\quad * * *$ : highly significant at 0.005 level of probability ns: no significant Ms: Mean square df: degrees of freedom

Table 3: The effect of sodium chloride concentration on proline content $\left(\mu \mathrm{g} \mathrm{g}^{-1} \mathrm{fw}\right)$ in fresh leaves of ten Hordeum vulgare L. varieties.

\begin{tabular}{|l|c|c|c|c|}
\hline Varieties & Control & 9000 PPm & 12000 PPm & 15000 PPm \\
\hline Giza 123 & $0.0000 \pm 0.0000$ & $0.7890 \pm 0.0000$ & $8.0740 \pm 0.0069$ & $11.6230 \pm 0.0035$ \\
\hline Giza 126 & $0.1120 \pm 0.0035$ & $0.8240 \pm 0.0069$ & $4.7260 \pm 0.0035$ & $6.9740 \pm 0.0849$ \\
\hline Giza 127 & $0.0443 \pm 0.0003$ & $0.4767 \pm 0.0101$ & $3.9077 \pm 0.0066$ & $6.6793 \pm 0.0032$ \\
\hline Giza 128 & $0.0000 \pm 0.0000$ & $3.7020 \pm 0.0035$ & $1.9130 \pm 0.0035$ & $1.5890 \pm 0.1022$ \\
\hline Giza 129 & $0.0000 \pm 0.0000$ & $2.6307 \pm 0.0032$ & $0.6060 \pm 0.0035$ & $0.3767 \pm 0.0066$ \\
\hline Giza 130 & $0.0620 \pm 0.0012$ & $6.0673 \pm 0.0032$ & $4.4900 \pm 0.0035$ & $1.9243 \pm 0.0032$ \\
\hline Giza 2000 & $0.0000 \pm 0.0000$ & $2.2127 \pm 0.0476$ & $11.2933 \pm 0.0101$ & $24.1110 \pm 0.0035$ \\
\hline El-Kheroba & $0.0000 \pm 0.0000$ & $3.7780 \pm 0.0000$ & $3.9840 \pm 0.0035$ & $7.8390 \pm 0.0069$ \\
\hline El-Sheikh Zuwaid & $0.0640 \pm 0.0012$ & $4.5610 \pm 0.0035$ & $6.9443 \pm 0.3398$ & $9.8927 \pm 0.0372$ \\
\hline Wadi Sedr & $0.1880 \pm 0.0000$ & $10.0220 \pm 0.0035$ & $10.8340 \pm 0.0035$ & $16.8550 \pm 0.0000$ \\
\hline
\end{tabular}

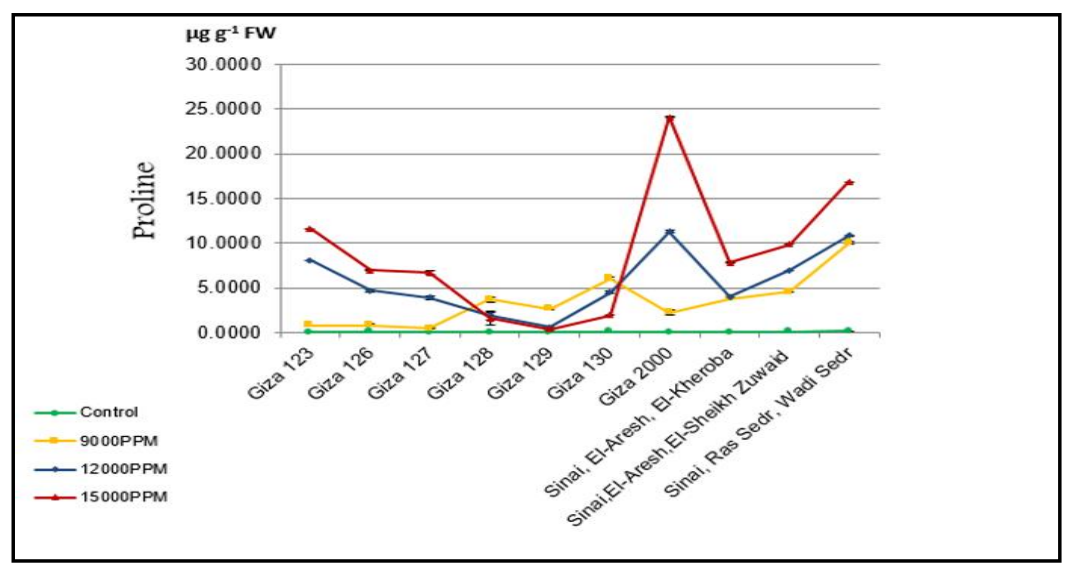

Fig. 3: Effect of salinity on proline content ( $\mu \mathrm{g} g-1 \mathrm{fw}$ ) in fresh leaves of ten Hordeum vulgare $\mathrm{L}$. varieties. 
From table (3) and figure (3) we can conclude that the proline plays an important role in enhancing the plant to tolerate salt stress. The maximum value of proline concentration is found in Giza 2000 and Wadi Sedr, both varieties were more tolerant to salt stress with sodium chloride while Giza 129 were sensitive to salinity stress depended on proline content on variety.

The present results show that the mean performance of proline content in fresh leaves of ten Egyptian Hordeum vulgare L. varieties increase as the concentration of sodium chloride increases in the studied salt tolerance varieties, this agreed with ElHamamsy and Behairy (2015), who found that the proline accumulation was increased in all of the barley landraces by increasing the $\mathrm{NaCl}$ concentration. Tabatabaei, (2013) found that, the concentration of proline increase under salt stress in barley. Garthwaite et al., (2005) observed that the proline content was increased in Hordeum marinum and Hordeum vulgare when exposed to increasing in sodium chloride concentrations.

Vodičková and Zámečníková (2011) also observed a positive correlation between the proline content and osmotic potential in the leaves of spring barley were cultivated under salinity conditions; also, McCue and Hanson (1990) reported that the salt stress increases the accumulation of proline.

Al-Khayri (2002) stated that a significant proline accumulation occurred when increasing sodium chloride in palm callus, (Arbona et al., 2003) in Carrizo citrange; also Moradi and Ismail (2007) reported that, under salt stress, proline concentration increased significantly in the flag leaf of three lines of rice (Oryza sativa), while Çiçek and Çakirlar (2002) found that salt stress at different osmotic potential increased the amounts of proline in leaf tissues of two maize cultivars, but its accumulation was fast in one of them.

Salt stress induces an increase of proline accumulation in most cereal crops (Chaitanya et al., 2009; Ramanjulu and
Sudhakar, 2000; Lakmini et al., 2006 , Rao et al., 2008 and Tripathi1 et al., 2019 ). Also, similar findings were reported by Ramteke and Karibasappa, (2005) in grape genotypes. A positive correlation between the magnitude of free proline accumulation and stress tolerance has been suggested as an index for determining the stress tolerance potential of cultivars. The major reason for the increase in the proline concentration during water stress was due to lesser incorporation of continuously synthesized proline amino acid during proline synthesis (Sharma et al., 1987).

Proline has been suggested to play a functional role as osmoregulator under drought and salinity conditions, stabilization of proteins, prevention of heat denaturation of enzymes, and conservation of nitrogen and energy for the post-stress period (Aloni and Rosenshtein, 1984). However, elevated proline levels play an important role in the control of the activity of plasma membrane transporters involved in cell osmotic adjustment in barley roots (Dat et al., 2000). Besides osmotic adjustment other roles have been proposed for proline in osmotically stressed plant tissues: protection of plasma membrane integrity (Mansour, 1998), a sink of energy or reducing power (Verbruggen et al., 1996), a source for carbon and nitrogen (Ahmad and Hellebust, 1988 and Peng et al., 1996), or hydroxyl radical scavenger (Smirnoff and Cumbes, 1989 and Hong et al., 2000).

Finally, Acosta-Motos 2020 found that the accumulation of the most common osmolytes such as proline, polyamine, and glycinebetaine these molecules in the cytosol and organelles decreases plant internal osmotic potential, in response to the decrease in external soil osmotic potential, due to excessive accumulation of phytotoxic ions in the substrate. Consequently, the cell membrane and macromolecules integrity are maintained.

Isolation and Sequencing of $B A D H-1$ gene from Both Genomic DNA and cDNA and Estimation the Gene Expression of 
$B A D H-1$ gene under the Effect Of Salinity on the Most Tolerance and Sensitive Barley by Quantitative Real Time PCR:

The betaine aldehyde dehydrogenase $(\mathrm{BADH})$ gene plays a multifunctional role in plants. It is an important factor in fragrance production, abiotic stresses, and antibioticfree selection of transgenic plants. Recently, molecular studies have presented a new picture of this critical factor involved in abiotic stress responses via the MAPK (mitogen-activated protein kinase) signaling pathway in numerous plants ( Sinha et. al., 2011). It was found that BADH is a positive regulator of salt treatment via MAPK pathway in plants (Hashimi et al., 2018). The role of BADH in tolerating abiotic stresses can be shown in Figure (4). (Yu et al., 2014).

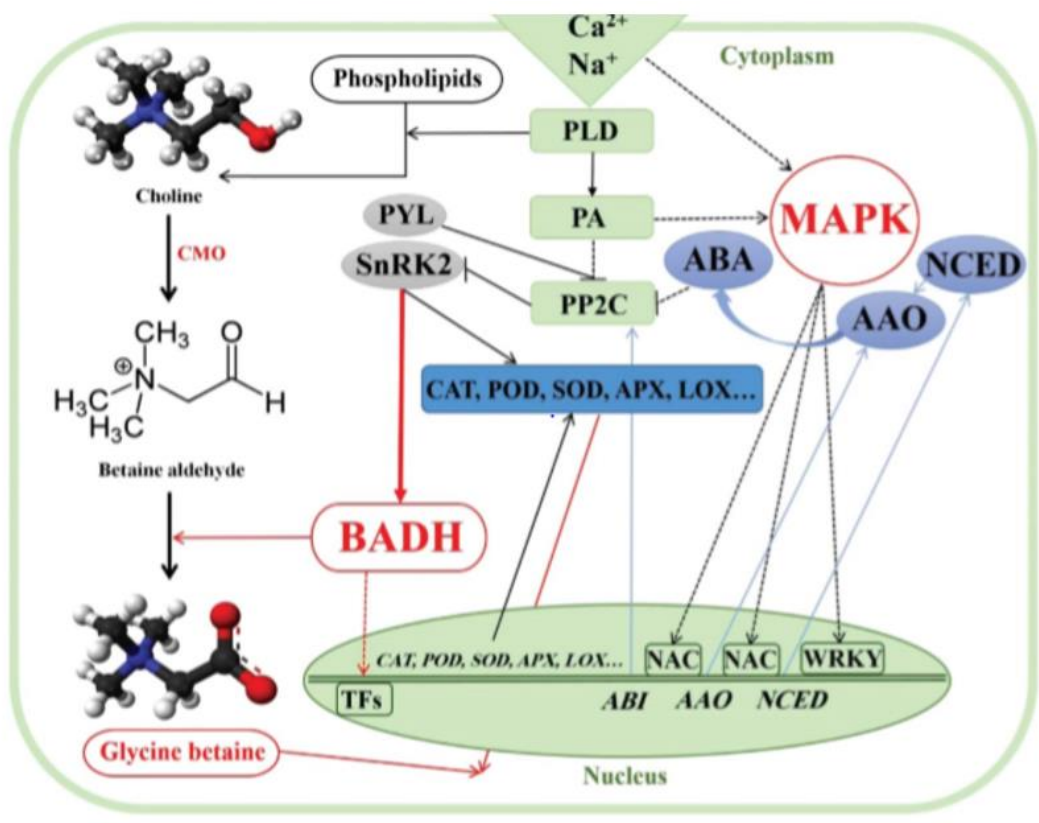

Fig. 4. The function of BADH in the tolerance to abiotic stresses via the MAPK signalling pathway, and also metabolic synthesis of glycine betaine in plants (Modified from $\mathrm{Yu}$ et al.(2017). Note: AAO, ABA-aldehyde oxidase; ABI, encoding gene for PP2C; APX, ascorbate peroxidase; CAT, catalase; CDPK, Ca2+-dependent calmodulin-independent protein kinase; $\mathrm{CMO}$, choline monooxygenase; MAD, malondialdehyde; MAPK, mitogen-activated protein kinase; NAC, NAC transcription factor; NCED, 9-cis epoxycarotenoid dioxygenase gene; PA, phosphatidic acid; PLD, phospholipase D; POD, peroxidase; PP2C, protein phosphatase $2 \mathrm{C}$; REL, relative electrolyte leakage; RWC, relative water content; SnRK2, sucrose non-fermenting 1-related protein kinase 2; SOD, superoxide dismutase; WRKY, WRKY transcription factors

Isolation and sequencing of BADH-1 gene from genomic DNA of barley:

Isolation of betaine aldehyde dehydrogenase- 1 genes by using a specific primer to amplify this gene from the genomic DNA of Giza 129 (sensitive cultivar to salt stress); also, from Giza 2000 and Wadi Sedr (tolerance to salt stress). The results of PCR-products obtained from using a specific primer (BADH-1 primer) gave an amplified band at a molecular size of $750 \mathrm{bp}$, as showed in figure (5).

The sequence of the $B A D H-1$ from the genomic DNA of Giza 129 cultivar (sensitive to salinity) gave 728 nucleotide base pairs. The $\mathrm{G}+\mathrm{C}$ content of this sequence was 334 nucleotide base pairs with a ratio of $45.88 \%$, while; the A+T content was 394 nucleotide base pairs with a ratio of $54.12 \%$. These gene sequences were submitted in the GenBank under accession number "KX433169". 
The comparison between the isolated gene sequence from genomic DNA from Egyptian barley cultivar Giza 129 and another gene sequences in the GenBank, by alignment the isolated sequence of $B A D H-1$ gene in GenBank by nucleotide blast (http://blast.ncbi.nlm), this alignment showed $100 \%$ identity while covered $51 \%$ in 371 base pairs with Hordeum vulgare BBD1 mRNA for betaine aldehyde dehydrogenase, complete cds under Accession Number "AB063179.1" by Nakamura et al., (2001).

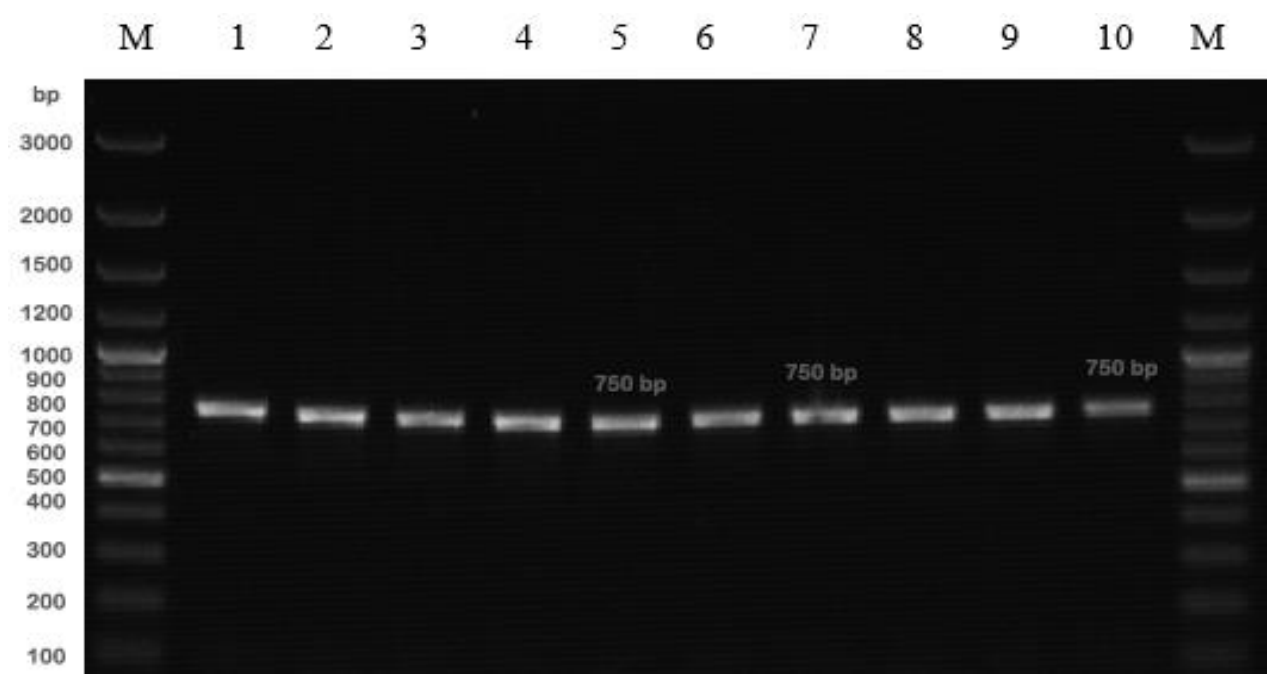

Fig. 5: Electrophoretic profile for $P C R$ product using one specific primer for $B A D H-1$ sequence in genomic DNA.

M= DNA Marker

Cultivars: 1-Giza 123, 2-Giza 126, 3-Giza 127, 4-Giza 128, 5-Giza 129, 6-Giza 130 and 7- Giza 2000.

Landraces: 8- El-Kheroba, 9- El-Sheikh Zuwaid, and 10- Wadi Sedr.

Also, it gave $99 \%$ identity while covered $51 \%$ in 370 base pairs with Hordeum vulgare subsp. vulgare mRNA for predicted protein, complete cds, clone: NIASHv2031D21 under Accession Number "AK365132.1" by Matsumoto et al., (2011), and $98 \%$ identity while covered $51 \%$ in 367 base pairs with Hordeum vulgare mRNA for betaine aldehyde dehydrogenase, complete cds under Accession Number D26448.1 by Ishitani et al., (1995).

The sequence of the $B A D H-1$ from the genomic DNA of Giza 2000 cultivar (tolerance to salinity) gave 728 nucleotide base pairs. The $\mathrm{G}+\mathrm{C}$ content of this sequence was 335 nucleotide base pairs with a ratio of $46.02 \%$, while the A+T content was 393 nucleotide base pairs with a ratio of $53.98 \%$. These gene sequences were submitted in GenBank under accession number "KX342849".

The comparison between the isolated gene sequence of genomic DNA from
Egyptian barley cultivar Giza 2000 and another gene sequences in the GenBank, by alignment the isolated sequence of $B A D H-1$ gene in GenBank by nucleotide blast (http://blast.ncbi.nlm), this alignment showed $99 \%$ identity while covered $51 \%$ in 370 base pairs with Hordeum vulgare BBD1 mRNA for betaine aldehyde dehydrogenase, complete cds under Accession Number "AB063179.1" by Nakamura et al., (2001). Also, it gave $99 \%$ identity while covered $51 \%$ in 369 base pairs with Hordeum vulgare subsp. vulgare mRNA for predicted protein, complete cds, clone: NIASHv2031D21 under Accession Number AK365132.1 by Matsumoto et al., (2011), and $99 \%$ identity while covered $51 \%$ in 368 base pairs with Hordeum vulgare mRNA for betaine aldehyde dehydrogenase, complete cds under Accession Number D26448.1 by Ishitani et al., (1995).

The sequence of the $B A D H-1$ from the genomic DNA of Wadi Sedr landrace 
(tolerance to salinity) gave 728 nucleotide base pairs. The $\mathrm{G}+\mathrm{C}$ content of this sequence was 334 nucleotide base pairs with a ratio of $45.88 \%$, while the A+T content was 394 nucleotide base pairs with a ratio of $54.12 \%$. These gene sequences were submitted in GenBank under accession number "KX433171".

The comparison between nucleotide sequences of the segment of $B A D H-1$ gene isolated from genomic DNA from Egyptian barley landrace Wadi Sedr obtained in this study and another gene sequences in the GenBank, by alignment the isolated sequence of $B A D H-1$ gene in GenBank by nucleotide blast (http://blast.ncbi.nlm). This alignment showed $100 \%$ identity while covered $51 \%$ in 371 base pairs with Hordeum vulgare BBD1 mRNA for betaine aldehyde dehydrogenase, complete cds under Accession Number "AB063179.1" by Nakamura et al., (2001). Also, it gave 99\% identity while covered $51 \%$ in 370 base pairs with Hordeum vulgare subsp. vulgare mRNA for predicted protein, complete cds, clone: NIASHv2031D21 under Accession Number "AK365132.1" by Matsumoto et al., (2011), and 98\% identity while covered $51 \%$ in 367 base pairs with Hordeum vulgare mRNA for betaine aldehyde dehydrogenase, complete cds under Accession Number D26448.1 by Ishitani et al., (1995).

Isolation and Sequencing of $B A D H-1$ gene from cDNA of Barley:

Isolation of betaine aldehyde dehydrogenase- 1 genes by using a specific primer to amplify this gene from cDNA of Giza 129 (sensitive cultivar to salt stress) also from Giza 2000 and Wadi Sedr (tolerance to salt stress). The results of PCRproducts obtained from using a specific primer $(B A D H-1$ primer) gave an amplified band at a molecular size of $410 \mathrm{bp}$, as showed in figure (6).

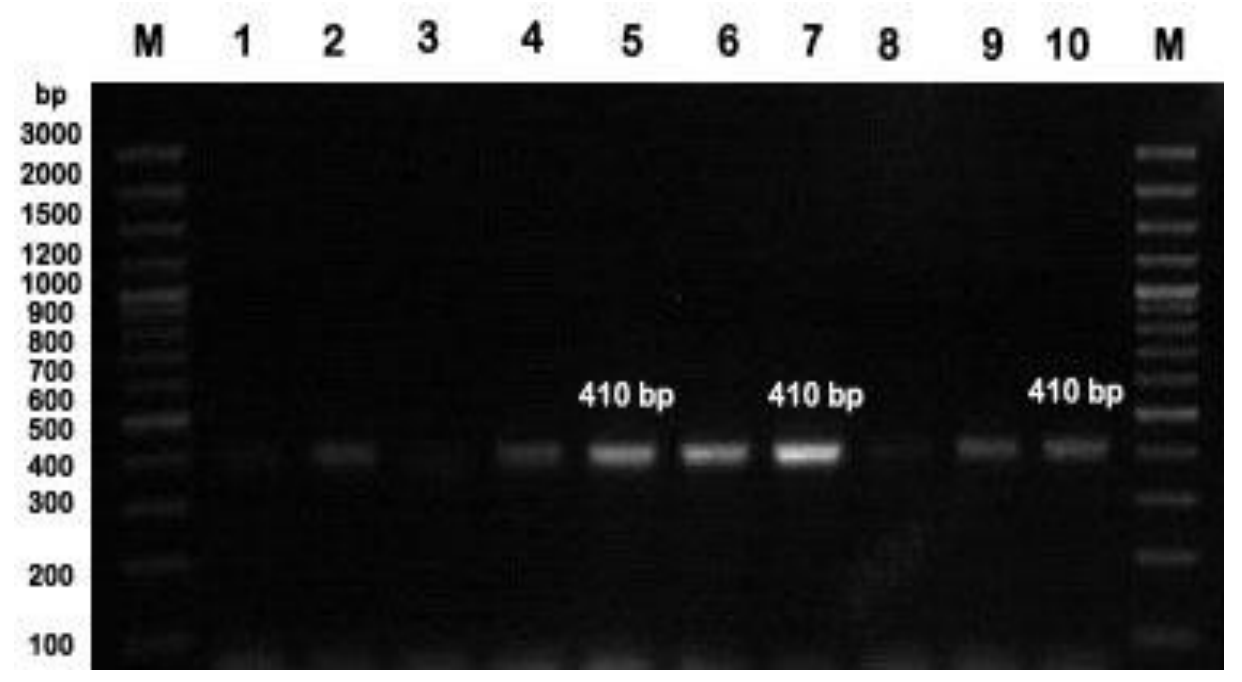

Fig. 6: Electrophoretic profile for PCR product using one specific primer for $B A D H-1$ sequence in cDNA.

M= DNA Marker

Cultivars: 1-Giza 123, 2-Giza 126, 3-Giza 127, 4-Giza 128, 5-Giza 129, 6-Giza 130 and 7- Giza 2000.

Landraces: 8- El-Kheroba, 9- El-Sheikh Zuwaid, and 10- Wadi Sedr.

The sequence of the $B A D H-1$ from cDNA of Giza 129 cultivar (sensitive to salinity) gave a 384 nucleotide base. The $\mathrm{G}+\mathrm{C}$ content of this sequence was 189 nucleotide base pairs with a ratio of $49.21 \%$, while the $\mathrm{A}+\mathrm{T}$ content was 195 nucleotide base pairs with a ratio of $50.78 \%$. These gene sequences were submitted in GenBank under accession number "KX342850". The comparison between nucleotide sequences of the segment of $B A D H-1$ gene isolated from cDNA from Egyptian barley cultivar Giza 129 and another gene sequences in the GenBank, by alignment the isolated 
sequence of $B A D H-1$ gene in GenBank by nucleotide blast (http://blast.ncbi.nlm), this alignment showed $100 \%$ identity while covered $100 \%$ in 384 base pairs with Hordeum vulgare BBDl mRNA for betaine aldehyde dehydrogenase, complete cds under Accession Number "AB063179.1" by Nakamura et al.,(2001). Also, it gave 99\% identity while covered $100 \%$ in 383 base pairs with Hordeum vulgare subsp. vulgare mRNA for predicted protein, complete cds, clone: NIASHv2031D21 under Accession Number AK365132.1 by Matsumoto et al., (2011), and 99\% identity while covered $100 \%$ in 380 base pairs with Hordeum vulgare mRNA for betaine aldehyde dehydrogenase, complete cds under Accession Number D26448.1 by Ishitani et al., (1995).

The sequence of the $B A D H-1$ from cDNA of Giza 2000 cultivar (tolerance to salinity) gave 384 nucleotide base pairs. The $\mathrm{G}+\mathrm{C}$ content of this sequence was 190 nucleotide base pairs with a ratio of $49.48 \%$, while the A+T content was 194 nucleotide base pairs with a ratio of $50.52 \%$. These gene sequences were submitted in GenBank under accession number "KX342851".

The comparison between nucleotide sequences of the segment of $B A D H-1$ gene isolated from cDNA from Egyptian barley cultivar Giza 2000 and another gene sequences in the GenBank, by alignment the isolated sequence of $B A D H-1$ gene in GenBank by nucleotide blast (http://blast.ncbi.nlm); this alignment showed 99\% identity while covered $100 \%$ in 383 base pairs with Hordeum vulgare BBD1 mRNA for betaine aldehyde dehydrogenase, complete cds under Accession Number "AB063179.1" by Nakamura et al.,(2001). Also, it gave 99\% identity while covered $100 \%$ in 382 base pairs with Hordeum vulgare subsp. vulgare mRNA for predicted protein, complete cds, clone: NIASHv2031D21 under Accession Number AK365132.1 by Matsumoto et al., (2011), and 99\% identity while covered $100 \%$ in 381 base pairs with Hordeum vulgare mRNA for betaine aldehyde dehydrogenase, complete cds under Accession Number D26448.1 by Ishitani et al., (1995).

The sequence of the $B A D H-1$ from cDNA of Wadi Sedr landrace (tolerance to salinity) gave 384 nucleotide base pairs. The $\mathrm{G}+\mathrm{C}$ content of this sequence was 189 nucleotide base pairs with a ratio of $49.21 \% \%$, while the $\mathrm{A}+\mathrm{T}$ content was 195nucleotide base pairs with a ratio of $50.78 \%$. These gene sequences were submitted in GenBank under accession number "KX433170".

The comparison between nucleotide sequences of the segment of $B A D H-1$ gene isolated from cDNA from Egyptian barley landrace Wadi Sedr obtained in this study and another gene sequences in the GenBank, by alignment the isolated sequence of $B A D H-1$ gene in GenBank by nucleotide blast (http://blast.ncbi.nlm), this alignment showed $100 \%$ identity while covered $100 \%$ in 384 base pairs with Hordeum vulgare BBD1 mRNA for betaine aldehyde dehydrogenase, complete cds under Accession Number "AB063179.1" by Nakamura et al.,(2001). Also, it gave 99\% identity while covered $100 \%$ in 383 base pairs with Hordeum vulgare subsp. vulgare mRNA for predicted protein, complete cds, clone: NIASHv2031D21 under Accession Number AK365132.1 by Matsumoto et al., (2011), and 99\% identity while covered $100 \%$ in 380 base pairs with Hordeum vulgare mRNA for betaine aldehyde dehydrogenase, complete cds under Accession Number D26448.1 by Ishitani et al., (1995).

\section{Transcription (Splicing Processing):}

The splicing process is occurred by editing the nascent pre-messenger RNA (premRNA) transcript, in which introns are removed and exons are joined together by ligation. In nuclear-encoded genes, splicing takes place within the nucleus immediately after transcription. In eukaryotic genes that contain introns, splicing is usually required in order to create an mRNA molecule that can be translated into protein.

Figures (7) represented the expression 
region or coding region (exon) and genomic DNA of $B A D H-1$ gene in three intervening sequences (intron) in the studied varieties.

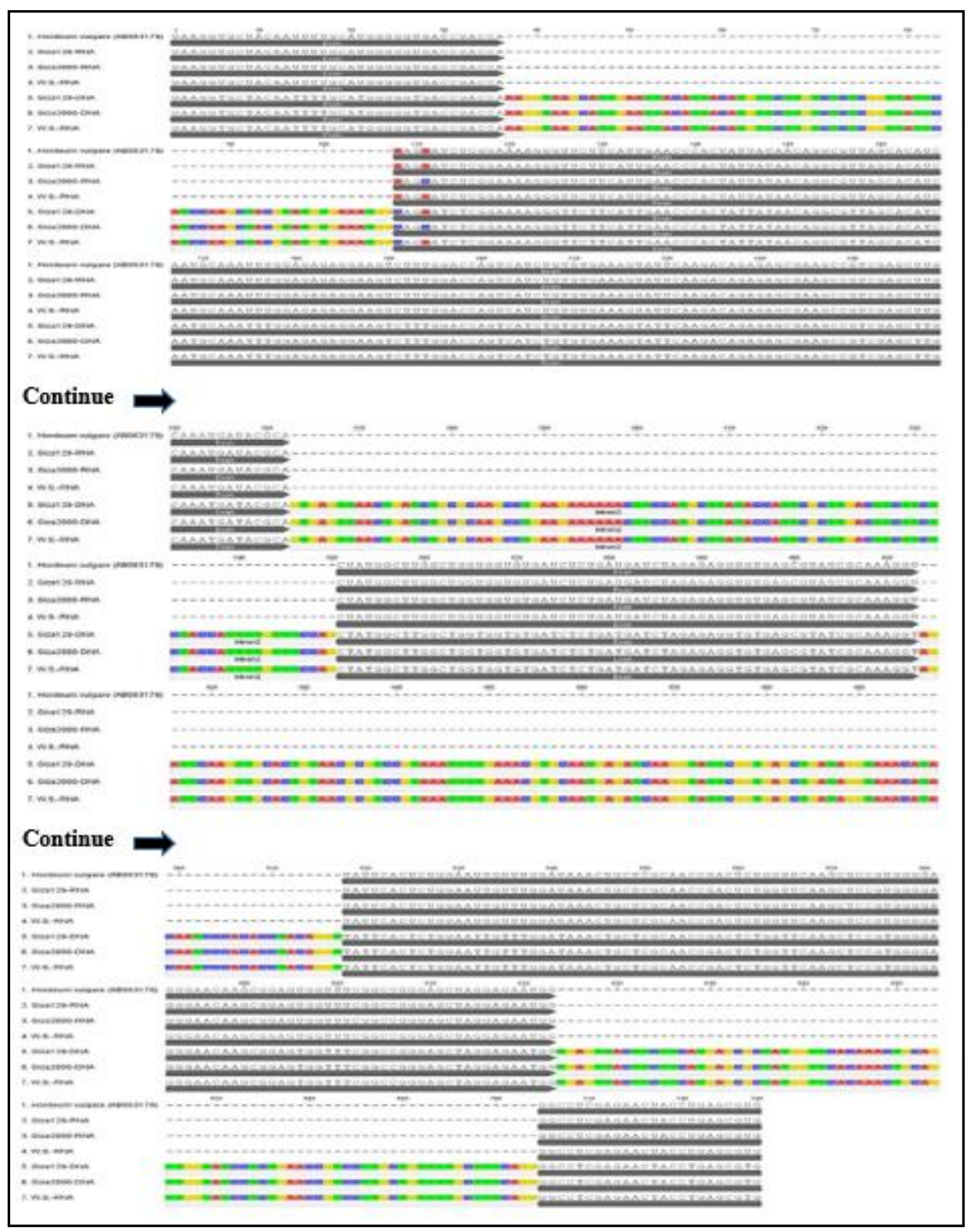

Fig. 7: Alignment between Genomic DNA and cDNA to determine Exon and Intron regions in three studied varieties.

Translation of mRNA into Protein:

The betaine aldehyde dehydrogenase 1 $(B A D H-1)$ protein sequence deduced from the cDNA gene of Giza 129 cultivar as predicted by computer analysis of the Blast Package Program (Altschul et al., 1997) gave 128 amino acids. It showed 100\% identity in 128 amino acids comparing with that reported by Nakamura et al., (2001) in Hordeum vulgare subsp. vulgare, submitted in the GenBank under accession number "BAB62847.1" as betaine aldehyde dehydrogenase. Also, it showed 98\% identity in 128 amino acids with that were reported by $\mathrm{Li}$ et al., (2009) as betaine aldehyde dehydrogenase in Agropyron cristatum, 
submitted in the GenBank under accession number "ACZ67850.1".

The betaine aldehyde dehydrogenase 1 $(B A D H-1)$ protein sequence deduced from the cDNA gene of Giza 2000 cultivar as predicted by computer analysis of the Blast Package Program (Altschul et al., 1997) gave 128 amino acids as showed in figure (8). It showed 99\% identity in 128 amino acids comparing to that reported by
Nakamura et al., (2001) in Hordeum vulgare subsp. vulgare, submitted in the GenBank under accession number "BAB62847.1" as betaine aldehyde dehydrogenase. Also, it showed 98\% identity in 126 amino acids with that reported by $\mathrm{Li}$ et al., (2009) as betaine aldehyde dehydrogenase in Agropyron cristatum, submitted in the GenBank under accession number "ACZ67850.1".

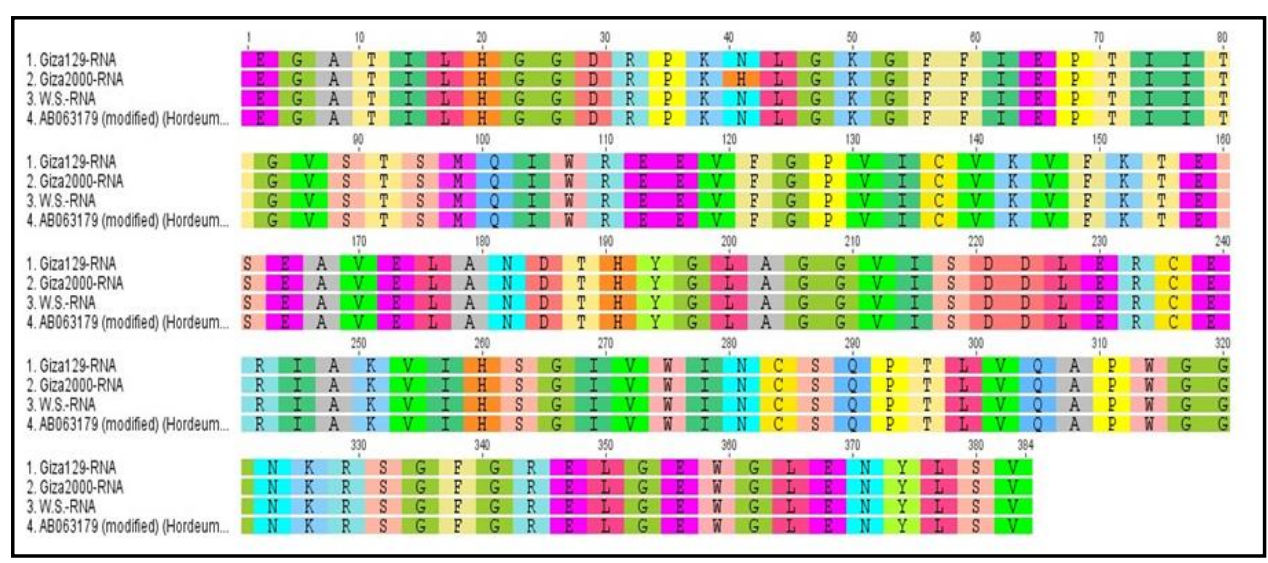

Fig. 8: The alignment of amino acid sequences of betaine aldehyde dehydrogenase 1 enzymes in three studied varieties (Giza 129, Giza 2000 and Wadi Sedr)

The betaine aldehyde dehydrogenase 1 $(B A D H-1)$ protein sequence deduced from the cDNA gene of Wadi Sedr landrace as predicted by computer analysis of the Blast Package Program (Altschul et al., 1997) gave 128 amino acids as shown in figure (9). ). It showed $100 \%$ identity in 128 amino acids comparing to that reported by Nakamura et al., (2001) in Hordeum vulgare subsp. vulgare, submitted in the GenBank under accession number "BAB62847.1" as betaine aldehyde dehydrogenase. Also, it showed $98 \%$ identity in 128 amino acids with that reported by $\mathrm{Li}$ et al., (2009) as betaine aldehyde dehydrogenase in Agropyron cristatum, submitted in the GenBank under accession number "ACZ67850.1.

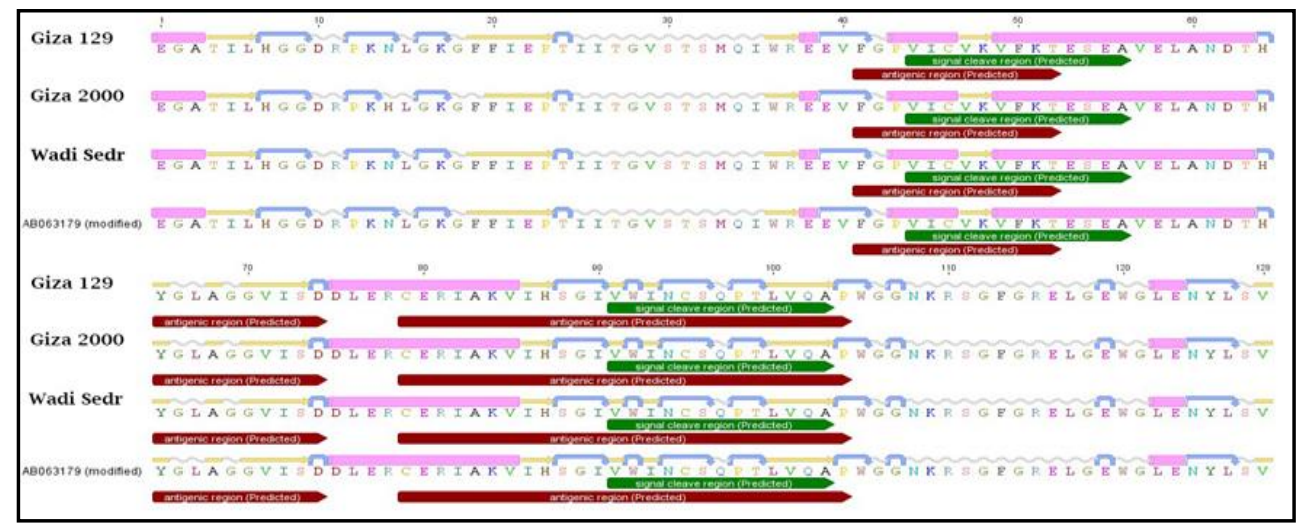

Fig. 9: Secondary structure of betaine aldehyde dehydrogenase enzyme in Giza 129, Giza 2000, and Wadi Sedr. 
The alignment of amino acid sequences of betaine aldehyde dehydrogenase 1 enzymes in three studied varieties (Giza 129, Giza 2000 and Wadi Sedr) were represented in figure (8). From alignment of amino acid sequence, we noted that, there is one amino acid differed in Giza 2000 only lead to the difference in coiling and turning of secondary structure of betaine aldehyde dehydrogenase 1 enzyme in Giza 2000 compared with other two varieties (Giza 129 and Wadi Sedr), as shown in figure (9).

\section{Gene Expression of $B A D H-1$ gene by} Quantitative Real Time PCR:

Betaine aldehyde dehydrogenae-1 (EC 1.2.1.8) play an important role in defense of the plant against abiotic stress as drought, salinity, and cold temperature, table (4) represented the $B A D H-1$ gene expression of one salt-sensitive barley cultivar (Giza 129) and two salt-tolerant barley varieties (Giza

2000 and Wadi Sedr) under the effect of $15000 \mathrm{PPm}$ of $\mathrm{NaCl}$ solution and control condition. In Giza 129, the gene expression of $B A D H-1$ under $15000 \mathrm{PPm}$ of $\mathrm{NaCl}$ thirteen-fold its expression under control while in Giza 2000 its expression under salt treatment 4.7 fold compared to control condition but in Wadi Sedr its expression under salinity 1.7 fold than in control condition, this means that this gene overexpressed in three studied varieties (Fig. 10).

Salinity effect on plant growth, the activity of major cytosolic enzymes by disturbing intracellular potassium homeostasis, causing oxidative stress and programmed cell death, reduced nutrient uptake, metabolic toxicity, inhibition of photosynthesis, reduce $\mathrm{CO}_{2}$ assimilation and reduced root respiration (Sairam and Srivastava, 2002; Cuin and Shabala 2007; Demirkiran et al., 2013 and Liu et al., 2014).

Table 4: RQ values of betaine aldehyde dehydrogenase-1 (BADH-1) gene expression in studied three Hordeum vulgare L. varieties under salt stress of $\mathrm{NaCl}$.

\begin{tabular}{|c|c|c|c|c|c|c|}
\hline Samples & $\begin{array}{c}\Delta \mathbf{C t}-15000 \\
\text { ppm }\end{array}$ & $\Delta$ Ct-cont & $\begin{array}{c}\text { RQ 15000 } \\
\text { ppm }\end{array}$ & RQ cont & $\Delta \Delta C T$ & RQ \\
\hline Giza 129 & -10.4113 & -6.707 & 1361.8 & 104.46 & -3.704 & 13.036 \\
\hline Giza 2000 & -7.897 & -5.661 & 238.36 & 50.594 & -2.236 & 4.711 \\
\hline Wadi Sedr & -6.0851 & -5.305 & 67.89 & 39.533 & -0.78 & 1.717 \\
\hline
\end{tabular}

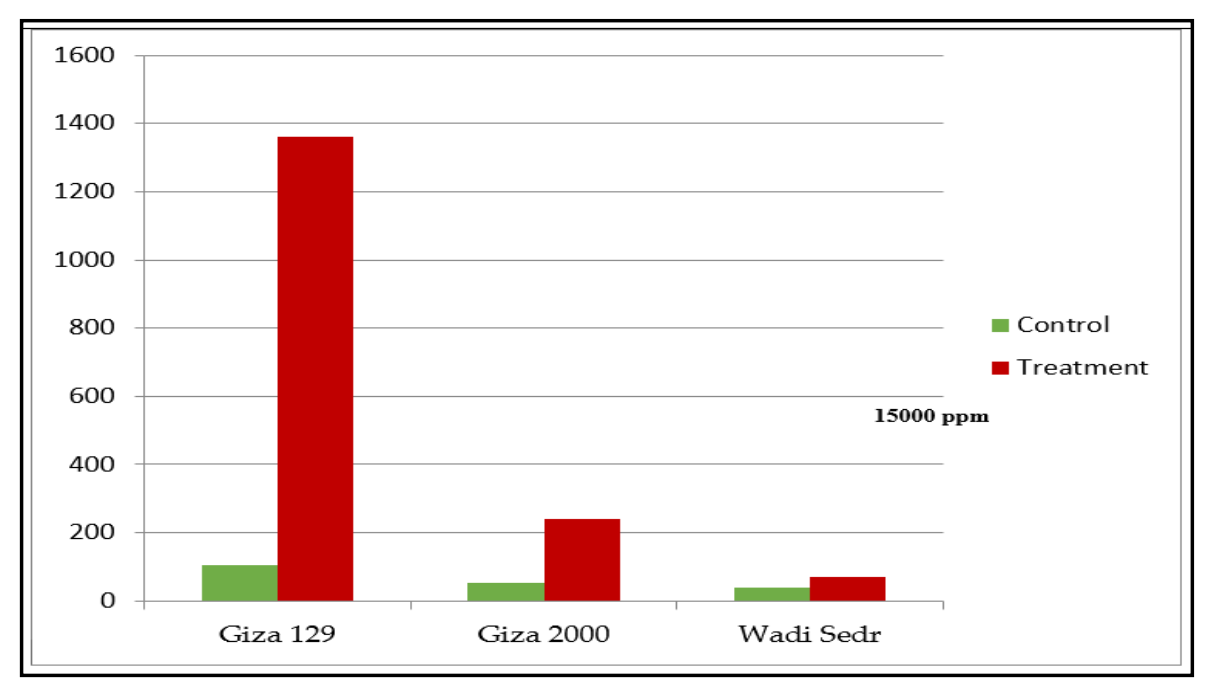

Fig. 10: RQ values of betaine aldehyde dehydrogenase-1 $(B A D H-1)$ gene expression in studied three Hordeum vulgare L. varieties under salt stress of $\mathrm{NaCl}$. 
In plants, $B A D H$ converts betaine aldehyde into glycine betaine (GB) in some halotolerant plants. Glycine betaine $(\mathrm{N}, \mathrm{N}$, $\mathrm{N}$-trimethylglycine) is an important quaternary ammonium compound that is produced in response to salt and other osmotic stresses in many organisms (Morgan, 1984). The GB plays an important role such as stabilizing the structures and activities of proteins and maintaining the integrity of membranes against the damaging effects of high salt, heat, cold, and freezing (Gorham, 1995).

The increase in $B A D H$ mRNA establishes that stress-induced betaine accumulation in plant involves modulation of the expression of a betaine biosynthesis gene (Yang et al., 1995).The biological effects of GB on plant stress tolerance have been shown using near-isogenic lines in maize and transgenic plants (Saneoka et al. 1995; Yang et al. 1995; Nomura et al. 1995; Sakamoto and Murata, 1998 and Mohanty et al. 2002). In near-isogenic lines of maize differing in levels of GB accumulation, lines with abundant GB showed higher salt tolerance than GB-deficient lines. However, most crop plants such as rice accumulate little GB and are sensitive to salt stress. Therefore, to improve plant salt tolerance, it is important to elucidate the mechanism of GB biosynthesis to potentially introduce the ability of GB production into GB nonaccumulators (Saneoka et al. 1995 and Yang et al. 1995).

Glycine betaine is thought to protect the plant by maintaining the water balance between the plant cell and the environment and by stabilizing macromolecules (Chen and Murata, 2002 and Rontein et al., 2002). Plants synthesize glycine betaine via twostep oxidation of choline: Choline $\rightarrow$ betaine aldehyde $\rightarrow$ glycine betaine (Rhodes and Hanson, 1993). The first reaction is catalyzed by ferredoxin-dependent choline monooxygenase (CMO) and the second step by an NAD+-dependent betaine aldehyde dehydrogenase (BADH) (Chen and Murata, 2002 and Rontein et al., 2002). Glycine betaine accumulation is associated with upregulated $\mathrm{CMO}$ and $\mathrm{BADH}$ gene expression concomitantly leading to elevated enzymatic activity. Glycine betaine accumulation marginally improves osmotic stress tolerance in transgenic plants (Hayashi et al., 1997). The levels of glycine betaine thus far obtained by engineering are low, and the increments in stress tolerance are small (Nuccio et al., 1999). The major factors that limit the accumulation of glycine betaine are the available choline as the substrate for the reaction and its transport from the chloroplast (where it is synthesized) to the cytosol (Nuccio et al., 1998 and 2000; McNeil et al., 2000; Huang et al., 2000; Chen and Murata, 2002 and Rontein et al., 2002).

Several investigators isolated $B A D H$ genes such as Liu et al., (2010), who isolated the full-length cDNA of betaine aldehyde dehydrogenase gene $(O j B A D H)$ from Ophiopogon japonicus using Reverse Transcriptase Polymerase Chain Reaction (RT-PCR) and Rapid Amplification of cDNA. The OjBADH gene (GenBank accession number: DQ645888) has 1785 nucleotides and encodes a polypeptide of 500 amino acids.

It has been reported that $B A D H$ gene in plants was included in a small multi-gene family. In barley, there is a small multi-gene family with 2 or 3 members 9 (Ishitani et al., 1995 and Weigel et al., 1986). Two members of the gene in Sorghum vulgare, Avicennia marina, and Atriplex triangularis have been cloned (He et al., 2004; Hibino et al., 2001 and Wood et al., 1996). However, the expression profiles and the position of enzyme protein-coding of the members from the $B A D H$ gene family are different.

Shrestha (2011) isolated and sequenced the $B A D H$ from three genomes of wheat and found that $\mathrm{T}$ blast $\mathrm{n}$ comparison of the deduced amino acid sequence of wheat $B A D H$ showed $100 \%$ identity with barley $B A D H$ paralogs. This high level of similarity in amino acid sequences with barley indicates that wheat $B A D H$ paralogs might 
also localize to two different sites in the wheat plant.

\section{CONCLUSION}

The present study revealed that, Giza 2000 and Wadi Sedr cultivars were the most tolerant to salt stress, so we can recommend the cultivation of both cultivars in salt soil. On the other hand, Giza129 was the most sensitive one and can be excluded. Also, there is a positive correlation between proline production and salinity. It was found that proline plays an important role in enhancing the plant to tolerate salt stress. The maximum value of proline concentration is found in Giza 2000 and Wadi Sedr. Both varieties were more tolerant to salt stress with sodium chloride. Molecular characterization of $(B A D H-1)$ gene was investigated from the most tolerant and sensitive cultivars, where, the sequencing of the gene was translated into amino acid sequences and these amino acid sequences were aligned in GenBank,.Finally, the secondary structure of $B A D H-1$ enzyme was detected.

\section{REFERENCES}

Abo-Elenin, R. A., Heakal, M. S., Gomaa, A. S., Moseman, J. G., 1981. Studies on salt tolerance in barley and wheat. II. Sources of tolerance in barley 681 germplasm.

Fourth International..Barley Genetics,. Symposium., Edinburgh., 394-401.

Acosta-Motos, J.R. , Penella,C. Hernández,J.A. * , Díaz-Vivancos,P. , Sánchez-Blanco, M. J., Navarro, J.M. , Gómez-Bellot, M.J. and BzarbaEspín,G. 2020. Towards a Sustainable Agriculture: Strategies Involving Phytoprotectants against Salt Stress. Agronomy, 10 (194):1-32

Ahmad, I., Hellebust, J. A., 1988. The relationship between inorganic nitrogen metabolism and proline accumulation in osmoregulatory responses of two euryhaline microalgae. Plant Physiology., 88 (2): 348-354.

Al-Khayri, J. M., 2002. Growth proline accumulation, and ion content in sodium chloride stressed callus of date palm. In vitro Cellular and Developmental. Biology.-Plant, 38 (1): 79-82.

Aloni, B., Rosenshtein, G., 1984. Proline accumulation: A parameter for evaluation of sensitivity of tomato varieties to drought stress. Physiologia. Plantarum., 61 (2): 231-235.

Altschul, S. F., Madden, T. L., Schäffer, A. A., Zhang, J., Zhang, Z., Miller, W., Lipman, D. J., 1997. Gapped BLAST and PSI-BLAST: a new generation of protein database search programs. Nucleic. Acids Research. 25 (17): 3389-3402.

Arbona, V., Flors, V., Jacas, J., GarcíaAgustín, P., Gomez-Cadenas, A., 2003. Enzimatic and non-enzimatic antioxidant responses of Carrizo citrange, a salt sensitive Citrus root stoock, to different levels of salinity. Plant Cell Physiology, 44 (4): 388-394.

Babu, S., Sheeba, A., Yogameenakshi, P., Anbumalarmathi, J., Rangasamy P., 2007. Effect of salt stress in the selection of salt tolerance hybrids in rice (Oryza Sativa L.) under in vitro and in vivo condition. Asian journal of Plant Science, 6 (1): 137-142.

Bates, L. S., Waldren, R. P., Teare, I. D., 1973. Rapid determination of free proline for water-stress studies. Plant Soil, 39: 205-207.

Chaitanya, K. V., Rasineni, G. K., Reddy, A. R., 2009. Biochemical responses to drought stress in mulberry (Morus alba L.): evaluation of proline, glycine betain and abscisic acid accumulation in five cultivars Acta Physiologiae Plantarum., 31 (3): 437-443.

Chen, T. H., Murata, N., 2002. Enhancement of tolerance of abiotic stress by metabolic engineering of betaines and other compatible solutes. Current. Opinion. in Plant Biology., 5 (3): 250 257.

Çiçek, N., Çakirlar, H., 2002. The effect of salinity on some physiological 
parameters in two maize cultivars. Bulgarian Journal of Plant Physiology, 28 (1-2): 66-74.

Cuin, T. A., Shabala, S., 2007. Compatible solutes reduce ROS induced potassium efflux in Arabidopsis roots. Plant and Cell Environment 30 (7): 875-885.

Dat, J., Vanadenabeele, S., Vranova, E., Van Montagu, M., Inzé, D., Van Breusegem, F., 2000. Dual action of the active oxygen species during plant stress responses.Cell. and Molecular. Life Science., 57 (5): 779-795.

Demirkiran, A., Marakli, S., Temel, A., Gozukirmizi, N., 2013. Genetic and epigenetic effects of salinity on in vitro growth of barley. Genetics. of Molecular. Biology., 36 (4): 566-570.

El-Hamamsy, S. M. A., Behairy, R. T., 2015. Effect of salinity stress on seedling vigor and biochemical characters of Egyptian barley landraces (Hordeum vulgare L.). Midle East Journal.of Applied., 5 (3): 786-796.

Fathi-Ettai, R. A., Prat, D., 1990. Variation in organic and mineral components in young Eucalyptus seedlings under saline stress. Physiologia Plantarum, 79 (3): 479-486.

Fujiwara, T., Hori, K., Ozaki, K., Yokota, Y., Mitsuya, S., Ichiyanagi, T., Hattori, T., Takabe, T., 2008. Enzymatic characterization of peroxisomal and cytosolic betaine aldehyde dehydrogenases in barley. Physiologia. Plantarum. 134 (1): 22-30.

Garthwaite, A. J., Von Bothmer, R. J., Colmer, T. D., 2005. Salt tolerance in wild Hordeum species is associated with restricted entry of $\mathrm{Na}+$ and $\mathrm{Cl}^{-}$ into the shoots. Journal. of Experimental. Botany., 56 (419): 23652378.

Gorham, J., 1995. Betaines in higher plants-biosynthesis and role in stress metabolism. In (RM Wallsgrove ed) "Amino acids and their derivatives in higher plants", Society for Experimental Biology Seminar Series, Cambridge University Press,
Cambridge, 56: 173-203.

Hall, T. A., 1999. Bio-Edit: a user friendly biological sequence alignment editor and analysis program for Windows 95/98/NT. Nucleic . Acids. Symposium. Serearch., 41: 95-98.

Hanson, A. D. M., May, A. M., Grumet, R., Bode, J., Jamieson, G. C., Rhodes, D., 1985. Betaine synthesis in chenopods: Localization in chloroplasts. Proceedings of the National Academic of Science of the United Stat of America., 82 (11): 3678-3682.

Hare, P. D., Cress, W. A., 1997. Metabolic implications of stress-induced proline accumulation in plants. Plant Growth Regulator 21 (2): 79-102.

Hashimi,F.S.G. , Mohd Razi Ismailb,c, Mohd Y. Rafii b,c, Farzad Aslanic, Gous Miahb and Farah Melissa Muharam 2018. Critical multifunctional role of the betaine aldehyde dehydrogenase gene in plants. Biotechnology \& Biotechnology. Equipment..,vol. 32,( 4), 815-829

Hayashi, H., Ali, A., Mustardy, L., Deshnium, P., Ida, M., Murata, N., 1997. Transformation of Arabidopsis thaliana with the codA gene for choline oxidase; accumulation of glycine betaine and enhanced tolerance to salt and cold stress. Plant Journal.International, 12 (1): 133-142.

He, X. L., Hou, X. L., Wu, J. Z., Liu, G. H., Qin, P., , Zhu, W. M., 2004. Molecular cloning and sequence analysis of betaine-aldehyde dehydrogenase $(\mathrm{BADH})$ in Atriplex triangularis. Journal. of Nanjing Agriculural. Univeristy.(JNAU), 27: 15-19.

Hibino, T., Meng, Y-L., Kawamitsu, Y., Uehara, N., Matsuda, N., Tanaka, Y., Ishikawa, H., Baba, S., Takabe, T., Wada, K., Ishii, T., Takabe, T., 2001. Molecular cloning and function characterization of two kinds of betaine accumulating mangrove Avicennia marina (Forsk.) Vierh. Plant Molecular Biolology, 45 (3): 53-63. 
Hong, Z., Lakkineni, K., Zhang, Z., Verma, D. P. S., 2000. Removal of feedback inhibition of $\Delta^{1}$-pyrroline-5carboxylate synthetase results in increased proline accumulation and protection of plants from osmotic stress. Plant Physiology, 122 (4): 1129-1136.

Huang, J., Hirji, R., Adam, L., Rozwadowski, K. L., Hammerlindl, J. K., Keller, W. A., Selvaraj, G., 2000. Genetic engineering of glycine betaine production toward enhancing stress tolerance in plants: metabolic limitations. Plant Physiology, 122 (3): 747-756.

Ishitani, M., Arakawa, K., Mizuno, K., Kishitani, S., Takabe, T., 1993. Betaine aldehyde dehydrogenase in the Gramineae levels in leaves of both betaine accumulating and nonaccumulating cereal plants. Plant and Cell Physiology, 34 (3): 493-495.

Ishitani, M., Nakamura, T., Han, S. Y., Takabe, T., 1995. Expression of the betaine aldehyde dehydrogenase gene in barley in response to osmotic stress and abscisic acid .Plant Molecular. Biology., 27 (2): 307-315.

Kishitani, S., Watanabe, K., Yasuda, S., Arakawa, K., Takabe, T., 1994. Acummulation of glycine betaine during cold acclimation and freezing tolerance in leaves in winter and spring barley plants. Plant Cell Environment.., 17 (1): 89-95.

Lakmini, W. G. D., Nainanayake, N. P. A. D., De Costa, W. A. J. M., 2006. Biochemical changes of four different coconut (Cocos nucifera L.) forms under moisture stress conditions. The Journal of Agricultural. Science., 2 (3): 1-7.

Le Rudulier, D., StrØm, A. R., Dandekar, A. M., Smith, L. T., Valentine, R. C., 1984. Molecular biology of osmoregulation. Scicence, 224 (4653): 1064-1068.

Li, S. S., Jia, N. T., Guo, X. Z., Zhu, H., Qi, Z. L., 2009. Cloning and sequencing of betaine aldehyde dehydrogenase (BADH) gene in Agropyron cristatum. Unpublished.

Liu, J., Gao, H., Wang, X., Zheng, Q., Wang, C., Wang, X., Wang, Q., 2014. Effects of 24-epibrassinolide on plant growth, osmotic regulation and ion homeostasis of salt stressed canola. Plant Biology, 16 (2): 440-450.

Liu, J., Zenga, H., Lia, X., Xua, L., Wanga, Y., Tang, W., Han, L., 2010. Isolation and characterization of betaine aldehyde dehydrogenase gene in Ophiopogon japonicas. The Open Biotechnology. Journal.l, 4: 18-25.

Maas, E. V., Hoffman, G. J., 1977. Crop salt tolerance current assessment. Journal. of Irrigation. and Drainage Division., 103: 115-135.

Mansour, M. M. F., 1998. Protection of plasma membrane of onion epidermal cells by glycine betaine and proline against $\mathrm{NaCl}$ stress. Plant Physiology and Biochemistry, 36 (10): 767-772.

Matsumoto, T., Tanaka, T., Sakai, H., Amano, N., Kanamori, H., Kurita, K., Kikuta, A., Kamiya, K., Yamamoto, M., Ikawa, H., Fujii, N., Hori, K., Itoh, T., Sato, K., 2011. Comprehensive sequence analysis of 24,783 Barley Full Length cDNAs derived from 12 clone libraries. Plant Physiology, 156 (1): 20-28.

McCue, K. F., Hanson, A. D., 1990. Salt inducible betaine aldehyde dehydrogenase from sugar sweet: cDNA cloning and expression. Trends Biotechnology., 8: 358-362.

McNeil, S. D., Rhodes, D., Russell, B. L., Nuccio, M. L., Shachar-Hill, Y., Hanson, A. D., 2000. Metabolic modeling identifies key constraints on an engineered glycine betaine synthesis pathway in tobacco. Plant Physiology, 124 (1): 153-162.

Mohanty, A., Kathuria, H., Ferjani, A., Sakamoto, A., Mohanty, P., Murata, N., Tayagi, A. K., 2002. Transgenics of an elite indica rice variety Pusa Basmati 1 harbouring the $\operatorname{cod} \mathrm{A}$ gene 
are highly tolerant to salt stress. Theoritical. and Appied Genetics. , 106 (1): 51-57.

Moradi, F., Ismail, A. M., 2007. Responses of photosynthesis, chlorophyll fluorescence and ROS-scavenging system to salt stress during seedling and reproductive stages in rice. Annual of Botany., 99: 1161- 1173.

Morgan, J. M., 1984. Osmoregulation and water stress in higher plants. Ann. Rev. of Plant Physiology, 35: 299-319.

Mori, N., Fuchigami, S., Kitamoto, Y., 2002. Purification and properties of betaine aldehyde dehydrogenase with high affinity for NADP from Arthrobacter globiformis. Journal. of Bioscience and Bioengineering., 93 (2): 130-135.

Munns, R., 2002. Comparative physiology of salt and water stress. Plant Cell Envirnment, 25 (2): 239-250.

Nakamura, T., Nomura, M., Mori, H., Jagendorf, A. T., Ueda, A., Takabe, T., 2001. An isozyme of betaine aldehyde dehydrogenase in barley. Plant and Cell Physiology, 42 (10): 1088-1092.

Nakamura, T., Yokota, S., Muramoto, Y., Tsutsui, K., Oguri, Y., Fukui, K., Takabe, T., 1997. Expression of a betaine aldehyde dehydrogenase gene in rice, a glycine betaine nonaccumulator, and possible localization of its protein in peroxisomes. The Plant Journal., 11: 1115-1120.

Nomura, M., Shitani, M. I., Takabe, T., Rai, A. K., 1995. Synechococcus sp. PCC 7942 transformed with Escherichia coli bet genes produces glycine betaine from choline and acquires resistance to salt stress. Plant Physiology, 107: 703708.

Nuccio, M. L., Russell, B. L., Nolte, K. D., Rathinasabapathi, B., Gage, D. A., Hanson, A. D., 1998. The endogenous choline supply limits glycine betaine synthesis in transgenic tobacco expressing choline monooxygenase. The Plant Journal., 16 (1): 101-110.

Nuccio, M. L., Rhodes, D., McNeil, S. D., and Hanson, A. D., 1999. Metabolic engineering of plants for osmotic stress resistance. Current Opinion. in Plant Biology., 2 (2): 128-134.

Nuccio, M. L., McNeil, S. D., Ziemak, M. J., Hanson, A. D., Jain, R. K., Selvaraj, G., 2000. Choline import into chloroplasts limits glycine betaine synthesis in tobacco: analysis of plants engineered with a chloroplastic or a cytosolic pathway. Metabolism Engineering., 2 (4): 300-311.

Peng, Z., Lu, Q., Verma, D. S., 1996. Reciprocal regulation of D1-pyrroline5-carboxylate synthetase and proline dehydrogenase genes control levels during and after osmotic stress in plants. Molecular. and General Genetics, 253 (3): 334-341.

Ramanjulu, S., Sudhakar, C., 2000. Proline metabolism during dehydration in two mulberry genotypes with contrasting drought tolerance. Journal of Plant Physiology, 157 (1): 81-85.

Ramteke, S. D., Karibasappa, G. S., 2005. Screening of grape (Vitis vinifera) genotypes for drought tolerance. Indian Journal. of Agricultuer. Science., 75 (6): 355-357.

Rao, P. B., Kaur, A., Tewari, A., 2008. Drought resistance in seedlings of five important tree species in Tarai region of Uttarakhand. Tropical. Ecolology., 49 (1): 43-52.

Rhodes, D., Hanson, A. D., 1993. Quaternary ammonium and tertiary sulfonium compounds in higher plants. Annual Review of Plant Physiology and Plant Molecular Biology, 44 (1): 357-384.

Robinson, S. P., Jones, G., 1986. Accumulation of glycine betaine in chloroplasts provides osmotic adjustment during salt stress. Australian.Journal of Plant Physiology , 13 (5): 659-668.

Rontein, D., Basset, G., Hanson, A. D., 2002. Metabolic engineering of osmoprotectant accumulation in plants. Metabolic Engineering., 4 (1): 49-56.

Sairam, R. K., Srivastava, G. C., 2002. 
Changes in antioxidant activity in subcellular fraction of tolerant and susceptible wheat genotypes in response to long term salt stress. Plant Science, 162 (6): 897-904.

Sakamoto, A., Murata, A. N., 1998. Metabolic engineering of rice leading to biosynthesis of glycine betaine and tolerance to salt and cold. Plant Molecular Biology., 38(6):1011-1019.

Saneoka, H., Nagasaka, C., Hahn, D. T., Yang, W-J., Premachandra, G. S., Joly, R. J., Rodes, D., 1995. Salt tolerance of glycine betaine deficient and containing maize lines. Plant Physiology, 107 (2): 631- 638.

Sharma, B. B., Mageed, K. J. A., Wattal, P. N., 1987. Studies on water stress in kinnow as influenced by irrigation schedules and nitrogen applications. Indian Journal. of Horticultuer., 44 (12): $52-56$.

Shrestha, K, 2011. Analysis of betaine aldehyde dehydrogenase encoding genes in wheat', MSc thesis, Southern Cross University, Lismore, NSW.

Singh, A., Singh, P. K., Singh, R., Pandit, A., Mahato, A. K., Gupta, D. K., Tyagi, K., Singh, A. K., Singh, N. K., Sharma, T. R., 2010. SNP haplotypes of the BADH1 gene and their association with aroma in rice (Oryza sativa L.). Molecular. Breeding., 26 (2): 325-338.

Sinha AK, Jaggi M, Raghuram B, et al.2011. Mitogen-activated protein kinase signaling in plants under abiotic stress. Plant Signal. Behaviour.;6:196-203.

Smirnoff, N., Cumbes, Q. J., 1989. Hydroxyl radical scavenging activity of compatible solutes. Phytochem., 28 (4): 1057-1060.

Tabatabaei, S. A, 2013. Changes in proline, protein, catalase and germination characteristics of barley seeds under salinity stress. International Research Journal of Applied. and Basic Science. (IRJAPS), 5 (10): 1266-1271.

Tamura, K., Stecher, G., Peterson, D., Filipski, A., Kumar, S., 2013.
MEGA6: Molecular Evolutionary Genetics Analysis version 6.0. Molecular. Biolology. and Evolution., 30: 2725-2729.

Tripathi1, P. A. Chandra1,A. and Prakash,J.2019. Physio-biochemical assessment and expression analysis of genes associated with drought tolerance in sugarcane (Saccharum spp. hybrids) exposed to GA3 at grand growth stage. Plant Biology 21:45-53 ,ISSN 1435-8603 German Society for Plant Sciences and The Royal Bot.l Society of the Netherlands.

Verbruggen, N., Hua, X-J., May, M., Van Montagu, M., 1996. Environmental and developmental signals modulate proline homeostasis: evidence for a negative transcriptional regulator. Proceed. of the National Academic of Science. of the United Stat of Agricultue., 93: 8787- 8791.

Vodičková, H., Zámečníková, B., 2011. Differences in proline content and osmotic potential in spring barley varieties grown under saline conditions. Scientific. Agricultuer. Botany.., 42 (2): 55-60.

Weigel, P., Lerma, C., Hanson, A. D., 1988. Choline oxidation by intact spinach chloroplasts. Plant Physiology, 86 (1): 54-60.

Weigel, P., Weretilnyk, E. A., Hanson, A. D., 1986. Betaine aldehyde oxidation by spinach chloroplasts. Plant Physiology, 82 (3): 753-759.

Wood, A. J., Saneoka, H., Rhodes, D., Joly, R. J., Goldsbrough, P. B., 1996. Betaine aldehyde dehydrogenase in sorghum (Molecular Cloning and Expression of Two Related Genes). Plant Physiology, 110 (4): 1301-1308.

Yang, W-J., Nadolska-Orczyk, A., Wood, K. V., Hahn, D. T., Rich, P. J., Wood, A. J., Saneoka, H., Premachandra, C. S., Bonham, C. C., Rhodes, J. C., Joly, R. J., Samaras, Y., Coldsbrough, P. B., Rhodes, D., 1995. Near isogenic lines of maize differing for glycine betaine. Plant Physiology, 107 (2): 621-630. 
Yu, H.Q., Zhou XY, Wang YG, et al.2017. A betaine aldehyde dehydrogenase gene from Ammopiptanthus nanus enhances tolerance of Arabidopsis to high salt and drought stresses. Plant Growth Regulator;83:265-276.

Yu, H.Q., Wang, Y.G., Yong, T.M., et al.2014. Heterologous expression of betaine aldehyde dehydrogenase gene from Ammopiptanthus nanus confers high salt and heat tolerance to Escherichia coli. Gene ; 549:77-84. 